\title{
ANALYSIS OF SELECTED ASPECTS OF ENERGY SECTOR - CASE STUDY FROM SKIERNIEWICE, POLAND
}

\author{
Karol Tucki, Anna Baczyk, Jedrzej Lelonkiewicz \\ Warsaw University of Life Sciences, Poland \\ karol_tucki@sggw.pl
}

\begin{abstract}
The aim of the paper was to analyse selected aspects of the energy sector in Poland. We analysed conventional methods of electric power production and provided an overview of conventional main activity electricity producers in Poland. The work contains a presentation of selected modernisation projects from the energy sector, characterisation of distribution system operators and analysis of the thermal power sector in Poland. Additionally, the article describes an enterprise operating in the thermal power engineering sector. The case study presented encompasses characterisation of a district heating plant located in Skierniewice, analysis of the heat generation process and description of the heat network programme. The study was based on literature, research and statistical data as well as on data provided by a thermal energy company LLC seated in Skierniewice. Additionally, employees of the company were interviewed during a site visit in the plant. The analysis of the thermal energy company LLC in Skierniewice allows us to conclude that the operation of undertakings specialising in the production of heat, which is to be used to heat buildings and supply hot water, differs depending on the quarter of the year, with 2 quarters of intense production (quarter I and IV - heating season) and 2 quarters of a reduced demand (quarter II and III - summer season). What is more, the company is required to comply with stringent standards for air pollutant emission. As a result of the above, there is a need for investments, which will have lower impact on the environment and will be performed in accordance with applicable regulations. In addition, the investments and modernisations aim to improve the efficiency of the equipment, reduce losses in the transmission of heat energy and enhance reliability of devices, all with a positive effect on the financial condition of the company.
\end{abstract}

Keywords: power industry, power plants, conventional energy, heat.

\section{Introduction}

In this day and age, when a joint climate and energy policy is being pursued by the European Union [1-4], optimisation of the energy sector is necessary in order to reduce the emission of dusts, carbon dioxide and nitrogen oxides. The modernisation-related challenges faced by the Polish power sector must both effectively ensure the energy security of the state and its competitiveness, and satisfy the requirements of sustainable development [5-8]. What is equally important is that all modernisation-oriented efforts need to be goaled at renewable energy sources [5]. Over $40 \%$ of all power units operated in Poland are older than 30 years, of which more than $15 \%$ already exceeded the age boundary of 50 and should be deactivated without undue delay [9].

It is estimated that approximately PLN 150-200 billion will be needed in the upcoming 15 years to carry out investments in new power units or to modernise the existing ones. Therefore, no wonder that financing such substantial investments from own funds may turn out to be too great a burden for the owners of the plants. Given the above, external sources of funds should be searched for [10].

The aim of this study was to analyse selected aspects of commercial power production in Poland. In part one, commercial electric power production in Poland was analysed and an overview of Polish power plants was provided. Additionally, selected modernisations in the energy sector were presented, and Distribution System Operators were characterised. Finally, heat production in Poland was analysed. In the second part of the article, the district heating plant in Skierniewice was described and the process of heat production and the heat network programme were characterised.

\section{Materials and Methods}

The project was based on a case study, as part of which a company from the heat sector was characterised, the heat production process was analysed and the heat network programme was outlined.

The study was based on literature, research and statistical data as well as on data provided by a thermal energy company under the business name Energetyka Cieplna Sp. z o.o. seated in Skierniewice. Finally, interviews with the company's employees were performed during the site visit. 


\section{Power plants in Poland and their modernisation}

In Poland, electric energy is mostly ensured by conventional main activity producer power plants, clustered into a production sub-system within the Polish National Power System (NPS). There are currently 14 main activity producer power plants in Poland, plus 19 main activity producer CHP plants and 177 subsidiary activity producer CHP plants. From among the 23 plants mentioned, only 6 use brown coal to produce power, while the rest are fuelled with hard coal. A number of power plants have recently been modernised, as a result of which they now use biomass combustion to produce energy. More than $70 \%$ of the plants are state-owned.

As further modernisation is needed, there are plans to introduce changes in the energy production system. Consequently, six of the selected investments mentioned above are going to use natural gas as the 'new' fuel (Tab. 1). Changes in the fuel structure of the electric power sector, which assume increased participation of gas, are motivated by the fact that, when compared to hard coal, gas offers numerous benefits as a fuel for power plants. One of the crucial and most obvious ones is smaller carbon dioxide footprint. Additionally, plans are to build nuclear power stations which would have the potential to be used as a new source of energy and a stabiliser and guarantor of energy security of the Polish economy [11]. Site characterisation works are currently in progress, aimed at selecting the best possible location for the future construction [12-15].

Table 1

Selected investments and modernisations, planned or already in progress, in the energy sector

\begin{tabular}{|c|c|c|c|c|c|c|}
\hline Items & $\begin{array}{c}\text { City/Town/Vill } \\
\text { age }\end{array}$ & Investor & $\begin{array}{c}\text { Electric } \\
\text { power, } \\
\text { MWe }\end{array}$ & $\begin{array}{c}\text { Thermal } \\
\text { power, } \\
\text { MWt }\end{array}$ & Fuel & $\begin{array}{c}\text { Planned time } \\
\text { of completion } \\
\text { of the } \\
\text { investment, } \\
\text { year }\end{array}$ \\
\hline $\begin{array}{c}\text { CHP plant in } \\
\text { Stalowa Wola }\end{array}$ & Stalowa Wola & $\begin{array}{c}\text { PGNiG } \\
\text { and Tauro } \\
\text { n }\end{array}$ & 450 & 240 & gas & 2018 \\
\hline $\begin{array}{c}\text { CHP plant in } \\
\text { Bydgoszcz }\end{array}$ & Bydgoszcz & PGE & 437 & - & gas & 2017 \\
\hline $\begin{array}{c}\text { CHP plant in } \\
\text { Gorzów }\end{array}$ & $\begin{array}{c}\text { Gorzów } \\
\text { Wielkopolski }\end{array}$ & PGE & 138 & 90 & gas & 2017 \\
\hline $\begin{array}{c}\text { CHPlant in } \\
\text { Płock }\end{array}$ & Płock & PKN Orlen & 596 & - & gas & $2017 / 2018$ \\
\hline $\begin{array}{c}\text { CHP plant in } \\
\text { Włocławek }\end{array}$ & Włocławek & PKN Orlen & 463 & - & gas & 2017 \\
\hline $\begin{array}{c}\text { Hydro-electric } \\
\text { power plant on } \\
\text { Vistula }\end{array}$ & Siarzewo & Energa & 80 & - & $\begin{array}{c}\text { hydro- } \\
\text { power }\end{array}$ & 2027 \\
\hline $\begin{array}{c}\text { Nuclear power } \\
\text { station }\end{array}$ & $\begin{array}{c}\text { Kubiatowo- } \\
\text { Żarnowiec }\end{array}$ & PGE & $2 \times 3000$ & - & nuclear \\
fuel & $\begin{array}{c}\text { site } \\
\text { characterisatio } \\
\text { currently in } \\
\text { progress }\end{array}$ \\
\hline
\end{tabular}

\section{Skierniewice Heating Plant}

The primary source of heat for the city of Skierniewice is the district heating plant, with 4 water heaters (three SR-25 heaters and one WR-10 heater) of the total power of 99.69 MW (Tab. 2). The main business of the plant's activity is to produce and deliver heat needed to heat buildings and water.

The main raw material used in heat production is hard coal, the contribution of which in 2015 equalled $97.25 \%$, with natural gas constituting only $2.75 \%$ in the overall fuel structure. The total length of the heat network equals $47.1 \mathrm{~km}$. The network encompasses high-parameter network (40.5 $\mathrm{km})$ and low-parameter network $(6.53 \mathrm{~km})$. The heat is sent to 339 thermal centres, and then to recipients. 
Technical parameters of heaters installed in the district heating plant

\begin{tabular}{|l|c|c|c|c|}
\hline Items & WR10 & WR25 no. 2 & WR25 no. 3 & WR25 no. 4 \\
\hline Installed power & 12.48 & 29.07 & 29.07 & 29.07 \\
\hline Year of handover for use & 1981 & 1981 & 1986 & 1994 \\
\hline${\text { Maximum flow, } \mathrm{t} \cdot \mathrm{h}^{-1}}^{\text {Calorific effect, GJ } \cdot \mathrm{h}^{-1}}$ & 160 & 360 & 360 & 360 \\
\hline $\begin{array}{l}\text { Pressure rating of water } \\
\text { behind the heater, Mpa }\end{array}$ & 0.65 & 0.65 & 0.65 & 0.65 \\
\hline $\begin{array}{l}\text { Maximum temperature of } \\
\text { water behind the heater, }{ }^{\circ} \mathrm{C}\end{array}$ & 154 & 154 & 154 & 154 \\
\hline $\begin{array}{l}\text { Temperature of feed } \\
\text { water, }{ }^{\circ} \mathrm{C}\end{array}$ & 80 & 70 & 70 & 70 \\
\hline
\end{tabular}

The volume of electricity consumption per a heat energy unit varies depending on the quantity of heat produced (Figure 1). In the quarters, when heat demand is increased, the production is bigger, with the volume of electricity consumption per a heat energy unit and the costs of production of $1 \mathrm{GJ}$ of heat being concurrently lower.

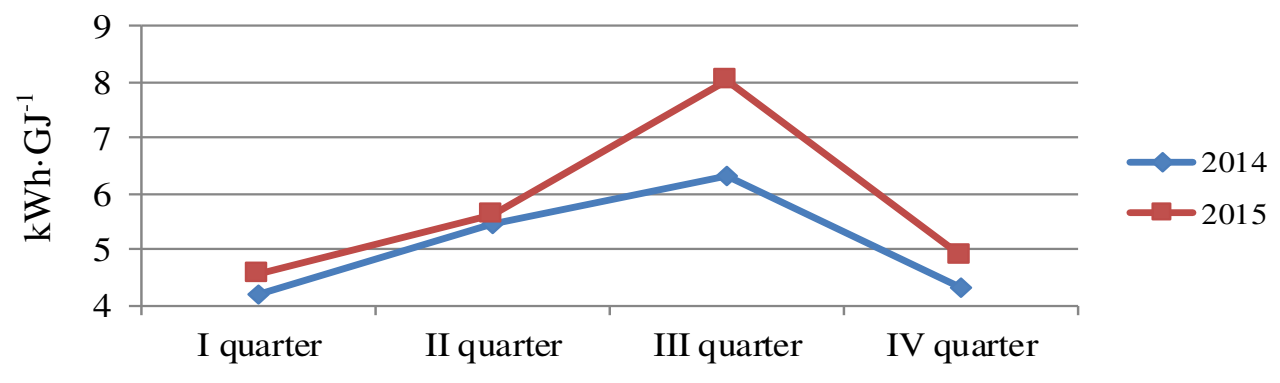

Fig. 1. Volume of consumption of electricity per heat energy unit, $\mathbf{k W h} \cdot \mathbf{G J}^{\mathbf{1}}$

The exchange of heat between flue gases produced in the process of fine coal combustion in the water heaters installed and the water that carries heat energy is possibly owing to the phenomenon known as convection, which occurs in convection bundles. The heat production process takes place under permanent supervision. The compatibility of the process with legal regulations governing the emission of pollutants to the air at Energetyka Cieplna Sp. z o.o. in Skierniewice is monitored by the Automatic Monitoring System (AMS), a tool used to supervise and measure the emission of substances released into the atmosphere.

The district heating plant houses the following rooms: pump room, outlet manifold hall, heater hall and water treatment station with a degasifier (Fig. 4). The plant and the district heating system were designed to work in the quality control system. This means that the system works in the environment of uniform flow and that heat energy supply is adjusted by changing the temperature of water which goes out of the plant. Nevertheless, as the automation of thermal centres progresses, uniform flow is impossible to ensure, as a result of which the supply of heat energy is adjusted through changes of temperature and flow of the heat transfer medium. Together with the technological progress connected with the use of automation grows the necessity to create a method that would allow us to control the load of the plant in a manner suitable for the specific heat source and concurrently guarantee that the variable demand of the users will be satisfied.

Operation of the district heating plant in Skierniewice is based on a double-pipe heating network fed from the District Heating Plant. The energy carrier is water of the maximum temperature of $120^{\circ} \mathrm{C}$ and maximum pressure of 16 bars (Table 3). 
Selected working parameters of a heating system in the district heating plant

\begin{tabular}{|l|c|c|}
\hline \multicolumn{1}{|c|}{ Parameters of the heat transfer medium: } & Heating season & Summer season \\
\hline - design temperatures & $120 / 65^{\circ} \mathrm{C}$ & $65 / 30^{\circ} \mathrm{C}$ \\
\hline - maximum temperature & $115^{\circ} \mathrm{C}( \pm 5 \%)$ & $70{ }^{\circ} \mathrm{C}\left( \pm 5^{\circ} \mathrm{C}\right)$ \\
\hline Maximum available pressure & $550 \mathrm{kPa}$ & $380 / 460 \mathrm{kPa}$ \\
\hline Minimum available pressure & $450 \mathrm{kPa}$ & $330 / 410 \mathrm{kPa}$ \\
\hline Static pressure & $310 \mathrm{kPa}$ & $310 \mathrm{kPa}$ \\
\hline
\end{tabular}

Operation of the heating plant is based on quality/quantity temperature diagrams. The adopted heat network programme assumes that the temperature of heat energy carrier is stable and equals app. $65^{\circ} \mathrm{C}$ with the outdoor temperature of at least $10^{\circ} \mathrm{C}$. Together with decrease of the outdoor temperature, the temperature of the agent grows. When the outdoor temperature drops below $5^{\circ} \mathrm{C}$, the temperature of the agent grows linearly until the maximum permitted temperature (app. $115^{\circ} \mathrm{C}$ ) is reached. The heat transmission agents reach the maximum permitted temperature, when the outside temperature drops to at least $-17^{\circ} \mathrm{C}$ (Fig. 2).

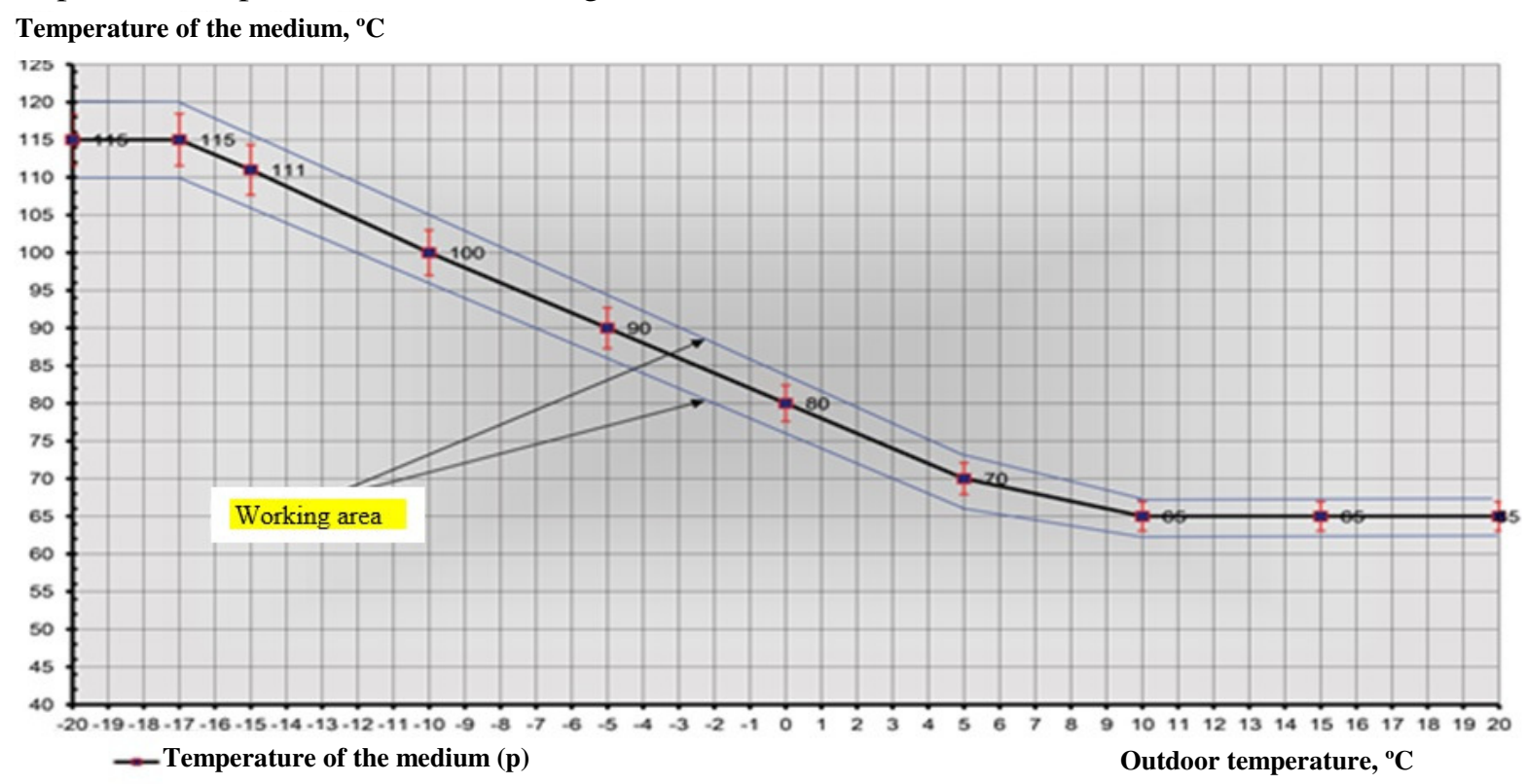

Fig. 2. Output temperature of heat energy carrier depending on outdoor temperature in heating season

The use of power looks similar. A drop of the outdoor temperature below $10^{\circ} \mathrm{C}$ causes linear increase in the generating power of the district heating plant (Fig. 3). The generating power is stable, when the outdoor temperature is equal to or higher than $12{ }^{\circ} \mathrm{C}$.

Production activity in the summer season boils down to heat production and supply in the form of hot water. As there is no need to heat buildings in the summer season and the transmission losses are lower, which is highly due to higher outdoor temperatures, the temperature of the heat transmission agent is stable and equals $65^{\circ} \mathrm{C}$ (with a tolerance of $5^{\circ} \mathrm{C}$ ).

In the summer season, the heat network can operate in two variants. The first one assumes operation under the maximum available pressure of $380 \mathrm{kPa}$ (tolerance: $-50 \mathrm{kPa}$ ), while the other one is based on operation under the maximum available pressure of $460 \mathrm{kPa}$ (tolerance: $-50 \mathrm{kPa}$ ). The adjustment of the maximum temperature derives from the need to stabilise the net flows. The role of pumps installed in the controllable circulating hot and cold air mixing system is to maintain the appropriate available pressure. The maximum flow of the heat transmission agent through the heating centre on the primary side equals $G_{s \max }=600 \mathrm{t} \cdot \mathrm{h}^{-1}$, while the minimum flow equals Gsmin $=200 \mathrm{t} \cdot \mathrm{h}^{-1}$ (Table 5). 


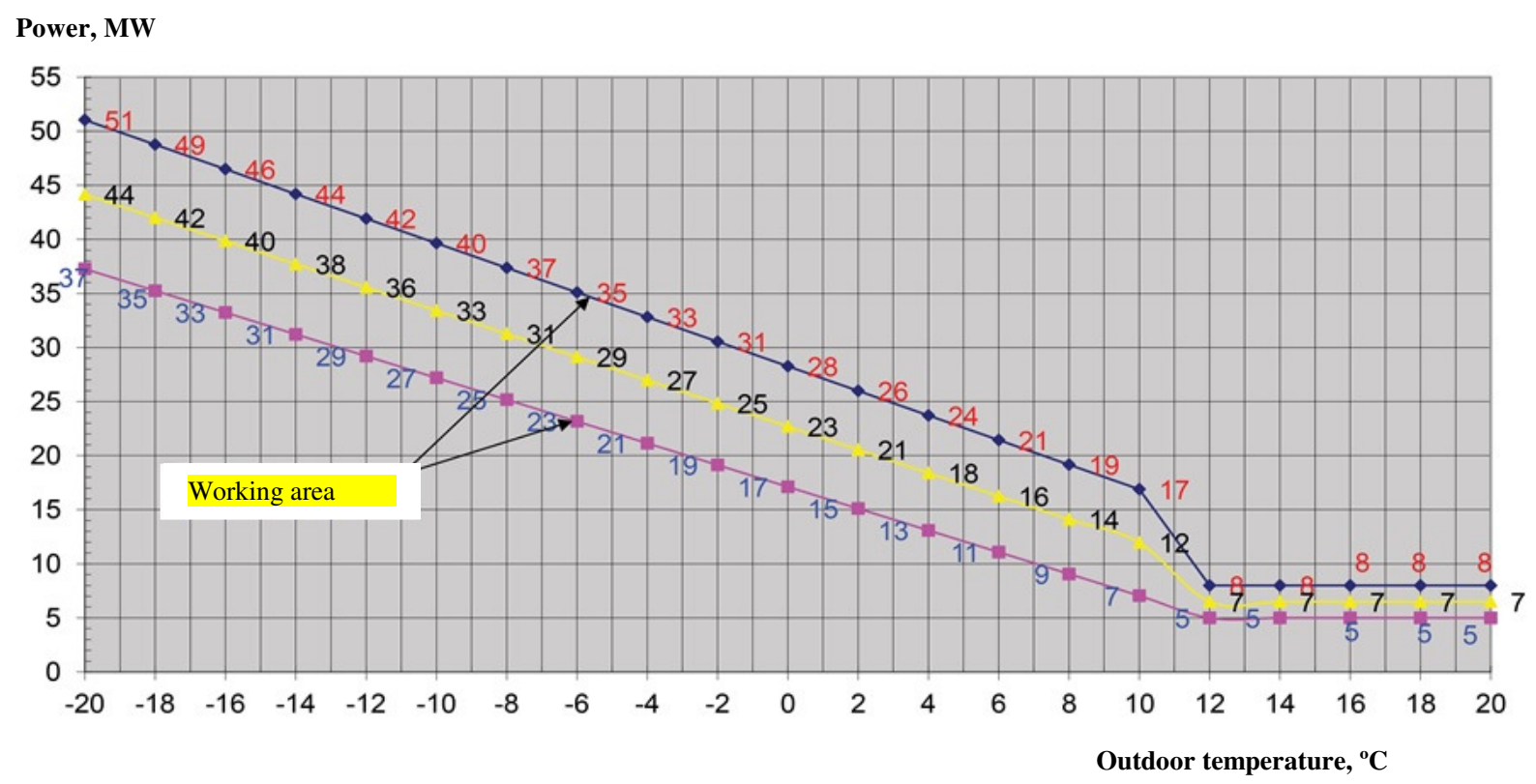

Fig. 3. Power production based on depositional properties of heat network in heating season

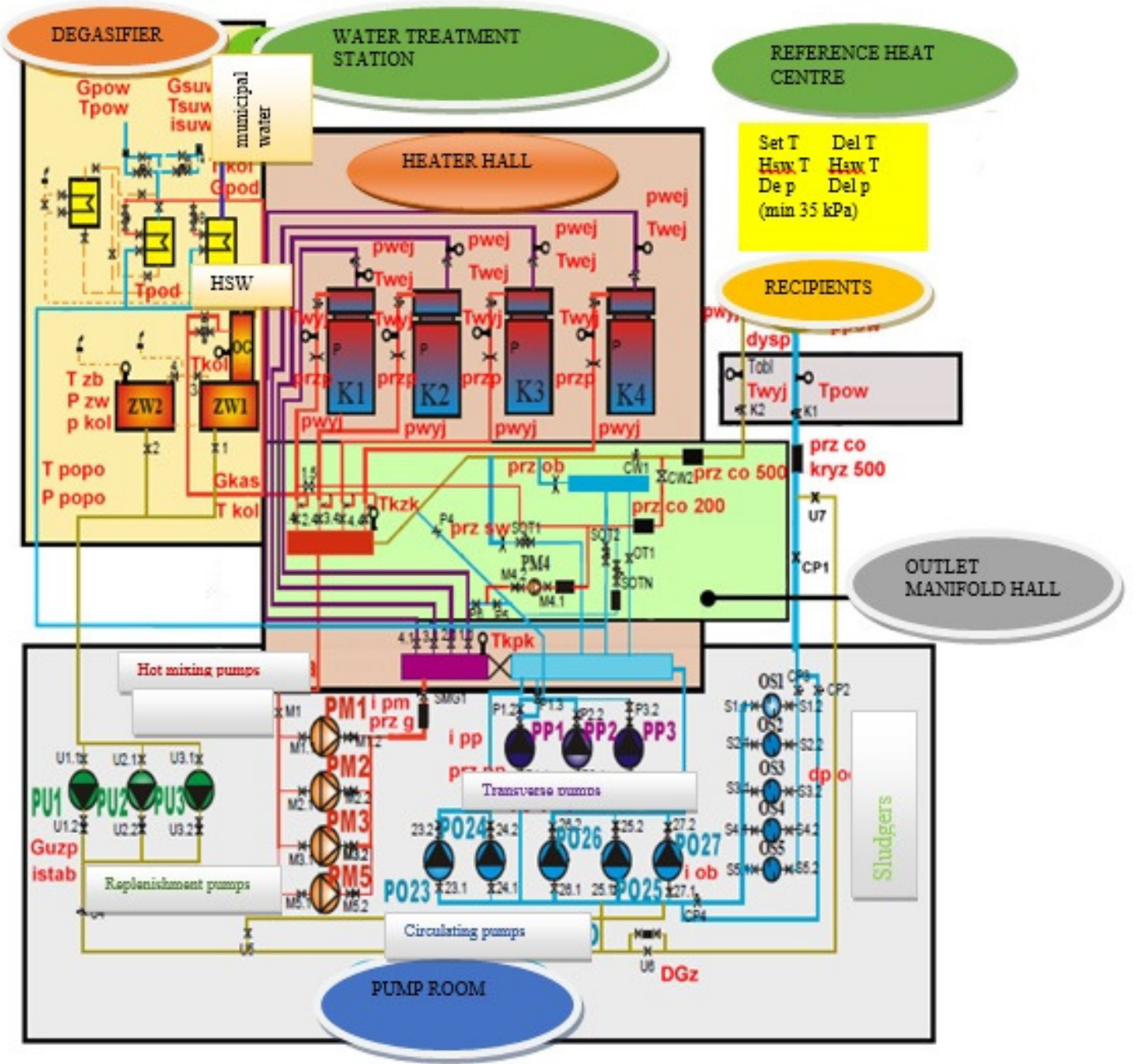

HSW - Hot Srervice Water

Fig. 4. Diagram of district heating plant in Skierniewice 


\section{Conclusions}

The analysis of selected aspects of the commercial power sector shows that the sector's nature is mostly determined by domestic resources. Power production in Poland is based on rich reserves of hard and brown coal. Although their participation is slowly declining, they still remain on a significant level. Changes in the fuel structure of the Polish energy sector are dictated by the necessity to reduce air pollutant emissions. Moreover, investments are needed in order to build new or modernise the existent obsolete power units that are unable to satisfy the requirements of the legal regulations and standards. A similar thesis concerning the future significance and participation of hard coal is also pursued by literature sources. We need changes that will reduce the contribution of coal fuels whilst allowing Poland to remain one of the most energetically secure Member States of the European Union. The diversification of the fuel structure shall mainly encompass the growth of RES and the number of power plants fuelled by natural gas. Nevertheless, sudden abandonment of energy production in power plants that use coal fuels is impossible, as they hold the majority of installed power and generate most of the energy in Poland.

Analysis of the company under the business name Energetyka Cieplna Sp. z o.o. in Skierniewice leads to the conclusion that the operation of main activity producers of heat to be used to heat buildings and supply hot water differs depending on the quarter of the year, with 2 quarters of intense production (quarter I and IV - heating season) and 2 quarters of reduced demand (quarter II and III summer season). What is more, the company analysed is obligated to satisfy rigorous standards of air pollutant emission. As a result, we need investments with reduced negative impact on the environment, which are to be carried out in line with applicable standards. Finally, the investments and modernisations aim to improve the efficiency of equipment, reduce losses in the transmission of heat energy and enhance reliability of devices, all with a positive effect on the financial condition of the company.

\section{References}

[1] Communication from the Commission to the Parliament, the Council, the European Economic and Social Committee and the Committee of Regions. Action Plan for a competitive and sustainable steel industry in Europe by 2050 (COM/2011/0885 final). [online] [22.04.2018]. Available at: http://eur-lex.europa.eu/legal-content/en/TXT/?uri=CELEX:52011DC0885

[2] Communication from the Commission to the Parliament, the Council, the European Economic and Social Committee and the Committee of Regions and the European Investment Bank. A Framework Strategy for a Resilient Energy Union with a Forward-Looking Climate Change Policy (COM/2015/80 final). [online] [22.04.2018]. Available at: http://eur-lex.europa.eu/legalcontent/EN/ALL/?uri=COM:2015:80:FIN

[3] Communication from the Commission to the Parliament, the Council, the European Economic and Social Committee and the Committee of Regions. A policy framework for climate and energy in the period from 2020 to 2030. [online] [22.04.2018]. Available at: https://eurlex.europa.eu/legal-content/EN/TXT/?uri=COM\%3A2014\%3A15\%3AFIN

[4] Communication from the Commission to the European Parliament, the Council, the European Economic and Social Committee, the Committee of the Regions and the European Investment Bank (COM/2016/860 final). [online] [22.04.2018]. Available at: https://ec.europa.eu/transparency/regdoc/rep/1/2016/EN/COM-2016-860-F1-EN-MAIN.PDF

[5] Miciuła I. Polityka energetyczna Unii Europejskiej do 2030 roku w ramach zrównoważonego rozwoju (Objectives and tasks of EU energy policy implementation in perspective 2030 within sustainable development). Studia i Prace Wydziału Nauk Ekonomicznych i Zarządzania, University of Szczecin Faculty of Economics and Management, Vol. 42, 2015, pp. 57-67. [online] [22.04.2018]. Available at: https://wneiz.pl/nauka_wneiz/sip/sip42-2015/SiP-42-t2-57.pdf (In Polish)

[6] Chandramowli S., Felder F., Climate change and power systems planning opportunities and challenges. The Electricity Journal, Vol. 27, 2014, pp. 40-50.

[7] Pacesila M., Gabriel S., Burcea S., Colesca S., Analysis of renewable energies in European Union. Renewable and Sustainable Energy Reviews, 2016, Vol. 56, pp. 156-170. 
[8] Kelsey N., Meckling J., Who wins in renewable energy? Evidence from Europe and the United States. Energy Research \& Social Science, Vol. 37, 2018, pp. 65-73.

[9] Łada A., Skłodowska M., Szczepanik M., Wenerski Ł., Unia Energetyczna z perspektywy Francji, Niemiec, Polski i Wielkiej Brytanii (The Energy Union: views from France, Germany, Poland and The United Kingdom). Institute of Public Affairs, Warszawa, 2015, pp. 93-123. [online] [22.04.2018]. Available at: http://www.isp.org.pl/uploads/pdf/1571114762.pdf (In Polish)

[10] Poddaniec P. The functioning of power boilers for renewable energy - the failure analysis and repair costs, master thesis, Warsaw University of Life Sciences, 2016, pp. 56-74.

[11]Polska Agencja Informacji i Inwestycji Zagranicznych S.A. (The Polish Information and Foreign Agency), Sektor Energetyczny w Polsce (Energy Sector in Poland), 2012. [online] [22.04.2018]. Available at: ttps://www.paih.gov.pl/files/?id_plik=19609 (In Polish)

[12] Komunikat prasowy dotyczący realizacji inwestycji budowy bloku energetycznego w Elektrowni Kozienice (Press release on the investment being construction of the power unit in Kozienice Power Plant). [online] [22.04.2018]. Available at: https://media.enea.pl/pr/324527/komunikatprasowy-dotyczacy-realizacji-inwestycji-budowy-bloku-energetycznego-w-elektrowni-kozienice (In Polish)

[13]Zaktualizowana strategia Grupy PGE w perspektywie 2020 roku (PGE Group's strategy update up to year 2020). [online] [22.04.2018]. Available at: https://www.gkpge.pl/Relacjeinwestorskie/Grupa/Strategia (In Polish)

[14] Na terenie Polski planowane są dwie zanieczyszczające środowisko inwestycje (Two environmental contamination projects are planned in Poland). [online] [22.04.2018]. Available at: http://odpowiedzialny-inwestor.pl/2018/03/10/na-terenie-polski-planowane-sa-dwiezanieczyszczajace-srodowisko-inwestycje/ (In Polish)

[15] Wielkie plany PGNiG. Inwestycje na poziomie $34 \mathrm{mld}$ zł (Great plans for PGNiG. Investments at the level of PLN 34 billion). [online] [22.04.2018]. Available at: http://gazownictwo.wnp.pl/wielkie-plany-pgnig-inwestycje-na-poziomie-34-mldzl,294018_1_0_0.html (In Polish) 